\title{
ИСПОЛЬЗОВАНИЕ ГЕОИНФОРМАЦИОННЫХ ТЕХНОЛОГИЙ ДЛЯ РЕШЕНИЯ ПРОБЛЕМ ВОДООБЕСПЕЧЕНИЯ СИРИИ
}

\section{Ольга Николаевна Николаева}

Российский государственный аграрный университет - МСХА им. К.А. Тимирязева, Институт мелиорации, водного хозяйства и строительства им. А.Н. Костякова, Россия, 127550, Москва, ул. Тимирязевская, 49, доктор технических наук, профессор кафедры экологической безопасности и природопользования, тел. (499)976-09-37;

Сибирский государственный университет геосистем и технологий, 630108, Россия, г. Новосибирск, ул. Плахотного, 10, проф. кафедры экологии и природопользования, тел. (383)361-08-86, e-mail: onixx76@mail.ru

\section{Кабтул Хала}

Российский государственный аграрный университет - МСХА им. К.А. Тимирязева, 127550 , Россия, г. Москва, ул. Тимирязевская, 49, обучающийся, e-mail: halak93@gmail.com

В статье обосновывается необходимость разработки системы регионального мониторинга поверхностных вод Сирии. Кратко охарактеризованы водные ресурсы Сирии. Изложены причины и виды техногенного ущерба, наносимого водоисточникам. Перечислены государственные органы, призванные контролировать качество водных ресурсов Сирии. Отмечен факт отсутствия сведений в доступных литературных и статистических источниках о программах и результатах мониторинга поверхностных вод Сирии. Сделан вывод о том, что подобные исследования ведутся несистемно, либо не ведутся вообще. Подчеркнута необходимость ведения регулярного мониторинга поверхностных вод для рационального использования имеющихся водных ресурсов и контроля их качества. Предложено использовать российские руководящие документы в качестве нормативно-методической основы. С учетом принятых в России принципов мониторинга поверхностных вод обоснована наблюдательная сеть постов для бассейна реки Барада. Намечены перспективы дальнейших исследований.

Ключевые слова: водные ресурсы, мониторинг поверхностных вод, качество поверхностных вод, водосборные бассейны, посты наблюдения, ГИС-технологии, цифровые карты

\section{GEOSPATIAL TECHNOLOGY FOR SOLVING THE WATER PROBLEM IN SYRIA}

\section{Olga N. Nikolaeva}

Russian State Agrarian University - Moscow Timiryazev Agricultural Academy, Institute of Amelioration, water management and construction named after A.N. Kostyakov, 49, Timiryazevskaya St., Moscow, 127550, Russia, Professor, Department of Environmental Safety and Natural Resources Management; phone: (499)976-09-37, e-mail: onixx76@mail.ru

Siberian State University of Geosystems and Technologies, 10, Plakhotnogo St., Novosibirsk, 630108, Russia, D. Sc., Professor, The Department of Ecology and Natural Resources Management, phone: (383)361-08-86

\section{Kabtoul Hala}

Russian State Agrarian University - Moscow Timiryazev Agricultural Academy, 49, Timiryazevskaya St., Moscow, 127550, Russia, Student, e-mail: halak93@gmail.com 
The article substantiates the need to develop a system for regional monitoring of surface waters in Syria. The water resources of Syria are briefly characterized. The reasons and types of technogenic damage caused to water sources are stated. State bodies designed to control the quality of water resources in Syria are listed. The fact of the lack of information in the available literary and statistical sources about the programs and results of monitoring the surface waters of Syria was noted. It is concluded that such studies are conducted unsystematically, or not at all. The need for regular monitoring of surface waters for the rational use of available water resources and control of their quality was emphasized. It is proposed to use Russian guidance documents as a regulatory and methodological basis. Taking into account the principles of surface water monitoring adopted in Russia, an observational network of monitoring stations for the Barada river basin was substantiated. Prospects for further research are outlined.

Keywords: water resource, water monitoring, water quality, drainage basin, monitoring station, GIS technologies, digital maps

Сирия, как и многие другие государства Ближнего Востока, характеризуется низкой обеспеченностью водными ресурсами. Ее основными водными артериями являются реки Евфрат и его притоки (в восточной части страны) и Оронт (Эль-Аси) (в юго-западной части). Значительная часть страны занята пустынными и полупустынными ландшафтами, для которых характерны сухие и пересыхающие водоемы и водотоки (вади), заполняющиеся водой только во время выпадения осадков.

Главным источником пресных вод в Сирии является река Евфрат. На территории Сирии расположено 22 \% ее бассейна, при этом 80\% речного стока поступает именно от Евфрата и его притоков [1]. Его ширина достигает 500 м, глубина - до 10 м, при паводках уровень воды дополнительно поднимается на 3-4 метра. Средний расход воды в Евфрате составляет около $700 \mathrm{M}^{3} / \mathrm{c}$, при этом максимальные значения в зимний сезон дождей колеблются около 3000 тыс. $\mathrm{M}^{3} / \mathrm{c}$, а минимальные наблюдаются в конце лета и составляют около $200 \mathrm{~m}^{3} / \mathrm{c}$. Годовой сток приблизительно равен 25 км³ [2]. В 1968-1973 гг. на Евфрате была построена крупнейшая в Сирии плотина - Эт-Табка (длина - 4,5 км, высота - 60 м), что позволило сформировать основное сирийское водохранилище Эль-Асад.

Значительный вклад в водообеспечение восточной части Сирии вносят также левые притоки Сирии - Белих и Хабур, воды которых интенсивно используются для орошения. Правые притоки Евфрата представляют собой типичные вади и не играют особой роли в водообеспечении территории.

В западной части страны основными водотоками являются реки Оронт (Эль-Аси), протекающая на границе Сирии и Ливана, и впадающая в Средиземное море, и Барада, расположенная в окрестностях Дамаска. Бассейн Барады образует одну из областей внутреннего стока, в устье которой находится оазис Гута. Барада в значительной степени обеспечивает водоснабжение столицы Сирии - Дамаска.

Основные гидрологические характеристики водотоков Сирии приведены в таблице $[2,3]$. 
Основные гидрологические характеристики водотоков Сирии

\begin{tabular}{|l|c|c|c|}
\hline $\begin{array}{l}\text { Наименование } \\
\text { реки }\end{array}$ & $\begin{array}{l}\text { Длина, км } \\
\text { сборного } \\
\text { сейна, км }\end{array} \quad \begin{array}{l}\text { водо- } \\
\text { бас- }\end{array}$ & $\begin{array}{l}\text { Расход } \\
\mathrm{M}^{3} / \mathrm{c}\end{array}$ \\
\hline Евфрат & 2700 & 673000 & 350 \\
\hline Оронт (Эль-Аси) & 571 & 22300 & 70 \\
\hline Хабур & 486 & 37081 & 6 \\
\hline Белих & 100 & 14400 & 3 \\
\hline Барада & 71 & 8600 & водь \\
\hline
\end{tabular}

Реки Сирии всегда подвергались достаточно интенсивному антропогенному прессингу, поскольку данный регион в силу засушливого климата относится к области орошаемого земледелия. Однако своего пика этот прессинг достиг в 70-80x гг. ХХ в., когда в долинах Оронта и Барады были возведены крупные промышленные предприятия по переработке нефти, производству нефтехимической продукции, цемента и удобрений. В результате значительно возрос забор воды на производственные нужды и резко увеличились объемы сбора сточных вод. В поверхностные и подземные водоисточники стали в большом количестве поступать химические соединения, технические масла, соли тяжелых металлов и другие токсичные загрязнители [4].

В XXI в. качество поверхностных водных ресурсов Сирии продолжало ухудшаться в ходе военных конфликтов и связанных с ними отрицательных воздействий на окружающую среду. Поскольку истоки Евфрата и его притоков находятся за пределами границ Сирии, сопредельные государства получили возможность оказывать политическое воздействие на страну, контролируя речной сток. Так, например, в 2014 году Турция полностью пресекла поступление воды из Евфрата в водохранилище Эль-Асад. В результате его уровень снизился на 6 м, лишив водоснабжения порядка 7 миллионов жителей [1].

В сложившихся условиях остро встает вопрос контроля качества поверхностных водотоков Сирии. На государственном уровне вопросы экологии вод призваны решать Министерство окружающей среды (The Ministry of Environment), Министерство водных ресурсов (The Ministry of Water Resources), Министерство сельского хозяйства и сельскохозяйственных реформ (The Ministry of Agriculture and Agrarian Reform) [5, 6]). Однако дальнейший анализ открытой печати не выявил детальных сведений о системных (общегосударственных) программах и результатах наблюдений, осуществляемых за водными ресурсами Сирии. Логично предположить, что таковые не выполняются в силу напряженной политической ситуации в стране. Также было установлено отсутствие нормативных документов, регламентирующих деятельность в области мониторинга и охраны окружающей среды Сирии, как на английском, так и на арабском языках.

Однако, даже самая неблагоприятная политическая ситуация не умаляет потребности населения в качественном водообепечении. В такой ситуации на первый план выступает роль регионального мониторинга, который должен быть организован максимально рационально и эффективно, с оптимальным балансом между затратами на выполнение работ и информативностью получаемых 
результатов и выводов. Решение этой задачи возможно благодаря использованию ГИС-технологий для ведения баз данных мониторинга поверхностных вод, а также для инвентаризационного и прогнозного картографирования состояния водных ресурсов.

Начальная стадия проектирования системы регионального мониторинга поверхностных вод предусматривает выбор местоположения для постов наблюдений. В отсутствии нормативной документации, разработанной в Сирии, в качестве исходного руководящего документа выступал Водный кодекс РФ, основные положения которого были адаптированы в соответствии с местными географическими и климатическими условиями.

Сеть створов регионального мониторинга поверхностных вод должна включать в себя:

- фоновые посты, расположенные в истоке или в максимально верхнем течении реки. Показатели, наблюденные на этих постах, характеризуют изначальное качество воды в водоисточнике, либо качество воды, поступающей из смежного государства. Наблюдения ведутся по полной программе (гидрологические, гидрохимические, гидробиологические показатели).

- региональный пост - располагается в устье реки (либо в точке выхода реки за государственную границу). Наблюденные показатели характеризуют состояние воды после прохождения через всю территорию водосборного бассейна. Наблюдения ведутся по полной программе (гидрологические, гидрохимические, гидробиологические показатели).

- импактные посты - располагаются ниже по течению основных источников техногенного воздействия (населенных пунктов, районов боевых действий), а также у впадения притоков. Наблюдения ведутся по сокращенной программе (гидрохимические показатели).

На рисунке приведена схема размещения постов регионального мониторинга воды, разработанная для бассейна р. Барада. Данная река была выбрана в качестве объекта исследования, поскольку она обеспечивает водными ресурсами почти 30\% населения страны, в том числе жителей Дамаска [3].
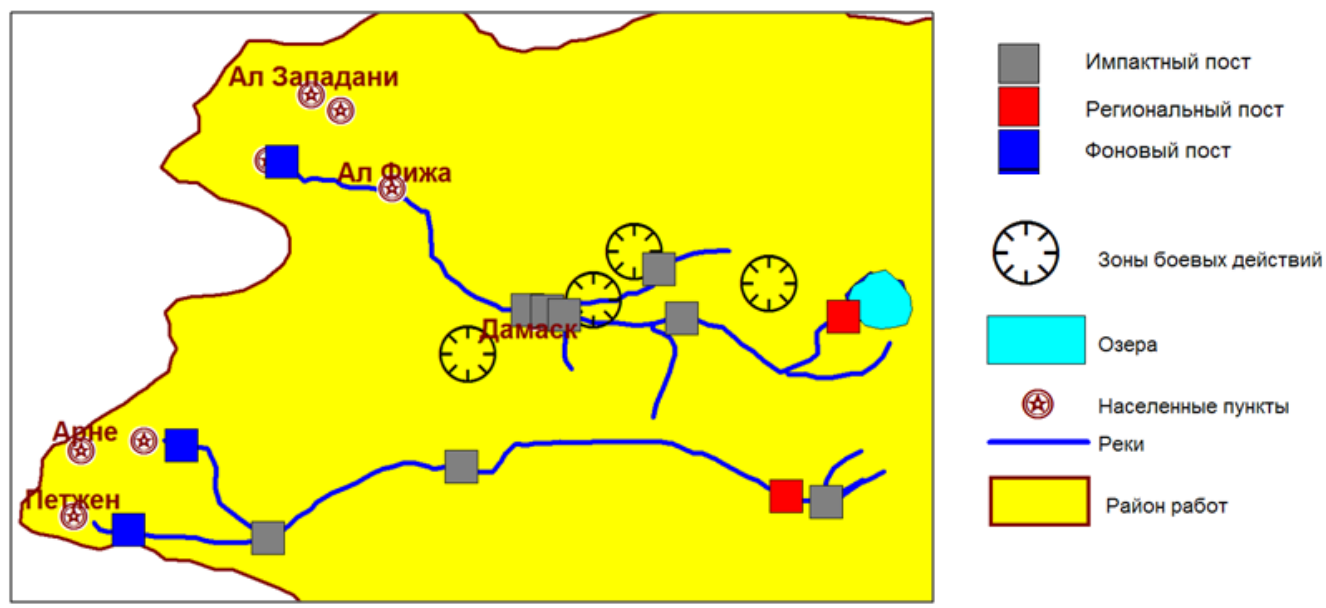

Схема наблюдательной сети мониторинга поверхностных вод в бассейне р. Барада 
Предлагаемая схема наблюдательной сети обеспечит достаточный для анализа объем данных, и в то же время не потребует значительных затрат на проведение работ. Приведенная цифровая карта является информационной основой для формирования и заполнения базы данных по результатам отбора и анализа проб.

Учитывая слабую выраженность времен года в Сирии (зимний и летний сезон отличаются в основном лишь колебаниями температуры воздуха), целесообразно проводить отбор проб 2 раза в год (по окончанию зимнего сезона, в течение которого выпадает основное количество осадков, и в конце лета, когда засушливость климата максимальна). Опционально в зависимости от региональных особенностей и материально-технических возможностей сюда можно включить третий пробоотбор, проводящийся в промежутке между 1-м и 2-м, и приуроченный к паводкам. Для контроля изменений береговой линии речных русел целесообразно применять данные дистанционного зондирования [7], в том числе, находящиеся в открытом доступе и предоставляемые бесплатно.

Дальнейшее развитие работ будет заключаться в детализации программ наблюдений на постах и разработке методики оперативной оценки и картографирования состояния водных ресурсов.

\section{БИБЛИОГРАФИЧЕСКИЙ СПИСОК}

1. Бояркина О.А. Водный фактор в турецко-сирийских отношениях // Мировая политика. 2017. - № 4. - С. 56 - 63. DOI: 10.25136/2409-8671.2017.4.18814.

2. Реки Ближнего Востока. Научно-информационный центр Межгосударственной координационной водохозяйственной комиссии Центральной Азии. Информационный сборник № 42, февраль 2015, Ташкент 2015. - С. 4.

3. Arraf, Firas. (2019). Causes of Decreasing Water Balances in the Barada Awaj (Damascus) Drainage Basin until the Uprising in Syria. Open Journal of Modern Hydrology. 09. 143-160. 10.4236/ojmh.2019.94008.

4. Ниязи А.Ш. Сирия: социально-экологические сдвиги накануне войны // Россия и мусульманский мир. - 2019. - №. 2 (312). - С. 75-83.

5. Water Management in Syria [Электронный pecypc]. - Режим доступа: https://water.fanack.com/syria/water-management/.

6. Ministry of state for environment affairs Syrian Arab Republic [Электронный ресурс]. Режим доступа: https://wedocs.unep.org/handle/20.500.11822/12504.

7. Крыленко В.В., Крыленко М.В. Уточнение длины береговой линии Азовского моря с использованием данных спутников Sentinel-2 // Вестник СГУГиТ. - 2018. - Т. 24, № 4. C. $78-92$.

(C) О. Н. Николаева, Кабтул Хала, 2021 